\title{
John F. Kennedy and the Race to the Moon
}

John M. Logsdon'

Abstract: This essay contains assessments of what Kennedy's commitment to the race to the Moon tells us about how John F. Kennedy carried out his duties as President of the United States; asks whether such a presidentially directed largescale undertaking can serve as a model for other such efforts; and evaluates the several impacts of Project Apollo. It carries out this last evaluation in terms of how well Apollo served the objectives sought by President Kennedy in sending Americans to the lunar surface, in terms of its impact on the evolution of the U.S. space program since the end of Project Apollo, and in terms of how humanity's first journeys beyond the immediate vicinity of their home planet will be viewed in the long sweep of history.

Keywords: Project Apollo; U.S. space program; Moon race; John F. Kennedy.

\section{John F. Kennedy e a corrida para a Lua}

Resumo: Este ensaio contém apreciações sobre o que o compromisso de Kennedy com a corrida para a Lua nos diz sobre como John F. Kennedy desempenhou suas funções como presidente dos Estados Unidos; pergunta-se se tal empreendimento em grande escala dirigido presidencialmente poderia servir de modelo para outros esforços desse tipo; e procura avaliar os vários impactos do Projeto Apollo. Realiza-se esta última avaliação em termos de quão bem o programa Apollo atendeu aos objetivos buscados pelo Presidente Kennedy de

1 George Washington University's Elliott School of International Affairs, Washington (DC) - United States of America - logsdon@gwu.edu 
enviar americanos à superfície lunar, quanto em termos de seu impacto na evolução do programa espacial dos EUA desde o final do Projeto Apollo e, por fim, em relação a como as primeiras viagens da humanidade além da vizinhança imediata de seu planeta natal serão vistas a longo prazo na história.

Palavras-chave: Projeto Apollo; Programa espacial dos Estados Unidos; Corrida à Lua; John F. Kennedy.

A half century has passed since Americans first landed on the Moon. Historian Arthur Schlesinger, Jr. some years ago suggested that "the $20^{\text {th }}$ Century will be remembered, when all else is forgotten, as the century when man burst his terrestrial bounds." 2 While the broadest historical significance of the initial journeys to Moon may indeed take centuries to fully appreciate, it is certainly possible to evaluate the impacts of the lunar landing program to date and of President John F. Kennedy's role in initiating the effort and continuing to support it until the day of his death. This essay contains my assessment of what Kennedy's commitment to the race to the Moon tells us about how John F. Kennedy carried out his duties as President of the United States; asks whether such a presidentially directed large-scale undertaking can serve as a model for other such efforts; and evaluates the several impacts of Project Apollo. I carry out this last evaluation in terms of how well Apollo served the objectives sought by President Kennedy in sending Americans to the lunar surface, in terms of its impact on the evolution of the U.S. space program since the end of Project Apollo, and in terms of how humanity's first journeys beyond the immediate vicinity of their home planet will be viewed in the long sweep of history.

\section{Understanding Kennedy's Commitment to Apollo}

In deciding to go to the Moon, and then reiterating that choice several times after extensive White House reviews, President Kennedy demonstrated with respect to space a steadiness of purpose and a clear understanding of the arguments for and against implementing his choice. He had the flexibility to pursue a cooperative path if it were open to him, but his judgment that space leadership was in the U.S. national interest made him determined to compete if competition was necessary. Kennedy as he announced his decision to go to the Moon

2 This essay is adapted from the closing chapter of my book John F. Kennedy and the Race to the Moon (New York, Palgrave Macmillan, 2010). Unless otherwise cited, quoted material in this essay comes from that book. 
warned the American public and their congressional representatives that the undertaking would be "a heavy burden, and there is no sense in agreeing or desiring that the United States take an affirmative position in outer space, unless we are prepared to do the work and bear the burdens to make it successful." As his science adviser Jerome Wiesner commented, "I think he became convinced that space was the symbol of the twentieth century. It was a decision he made cold bloodedly. He thought it was good for the country."

The decision to go to the Moon was a choice that reflected particularly American characteristics, such as the assumption that the U.S. democratic system of government was superior to all alternatives, that the United States was rightfully the exemplar for other nations, and that meeting challenges to the U.S. position as the leading world power justified the use of extensive national resources to achieve success. Not only the security of the United States was seen at stake; the decision reflected an almost messianic, expansive drive, one resulting in a sense of destiny and mission, which has for a long time been part of the American world view. The validity of this assumption of American exceptionalism is, of course, open to challenge, but that is not my point. Rather, I conclude that it was this perspective that justified in the minds of President Kennedy and many of his key advisers the decision to begin, as Kennedy said in his speech announcing the decision, what they knew would be an expensive and difficult "great new American enterprise" aimed at winning the battle between "freedom and tyranny" for the "minds of men everywhere who are attempting to make a determination of which road they should take."

President Dwight Eisenhower had come to a different judgment of the importance of space achievement (or rather its lack of importance) in terms of preserving U.S. global leadership, which he saw as being based more on a sound defense, fiscal soundness, and social stability. John Kennedy, with his much more activist approach to government, had an opposing view. Kennedy was not at all a visionary in the sense of having a belief in the value of future space exploration; rather, his vision was that space capability would be an essential element of future national power, and thus that the United States should not by default allow the Soviet Union to have a monopoly of large-scale capabilities to operate in "this new ocean." I believe that this was a wise judgment, one from which the United States has benefitted over the past half century. Perhaps the technical capabilities developed for Apollo were in fact too large and too expensive for subsequent regular use, but the principle that the United States should be the leading spacefaring nation has served the country well. 
As historian Walter McDougall observed, "perhaps Apollo could not be justified, but, by God, we could not not do it." Even the fiscally conservative Bureau of the Budget (BOB) agreed, commenting in a 1963 analysis that "we are inclined to agree with the conclusion that the fundamental justification at this time for a large-scale space program lies ... in the unacceptability of a situation in which the Russians continue space activities on a large scale and we do not."

\section{A Rational Choice?}

In my 1970 book The Decision to Go to the Moon, I portrayed Kennedy's 1961 decision to enter a space race with the Soviet Union as closely resembling the rational choice model of decision-making, in which a decision-maker identifies a desirable goal to be achieved or a problem to be addressed, assesses various options for achieving that objective, and selects the option with the best ratio of benefits to costs. It is important to note that what makes this decision process "rational" is the purposeful evaluation of alternatives to achieve a stated goal and the choice of the alternative that embodies the best relationship between benefits and costs; the goal itself is a matter of judgment, and must be evaluated on the quality of that judgment. My reconstruction of the decision process in April and May 1961 suggested that John Kennedy made the following judgments, each of which could be open to debate:

- Kennedy defined the U.S. national interest as requiring the country to be superior to any rival in every aspect of national power.

- This conviction reflected a Cold War interpretation of the international situation in which there was a zero-sum contest for global power and influence conducted between two sharply opposed social and political systems, one led by the United States and the other by the Soviet Union, with an uncommitted "Third World," and perhaps even more developed countries, deciding with which system it was better to associate.

- National prestige, Kennedy thought, was an important element of national power. As image-conscious as he was, Kennedy judged that what other nations thought about American power and resolve to use it was as important, if not more important, than the reality of that power. Kennedy once wondered aloud "What is prestige? Is it the shadow of power or the substance of power?" He concluded that prestige was a real factor in acquiring and exercising national power (Schlesinger, 1965: 276).

- Kennedy's own analysis, the answers he got from the many people he queried in the weeks following the April 12 launch of Yuri Gagarin, his 
assessment of the national and international reaction to that feat, and the advice he received from people like Vice President Lyndon Johnson and NASA Administrator James Webb convinced the president that dramatic space achievements were closely tied to national prestige and thus "part of the battle along the fluid front of the cold war." In addition, Kennedy judged that the potential contributions of space capabilities to military power justified a significant investment in developing those capabilities, albeit through a peaceful, civilian-led effort.

Once these judgments were made, the choice of sending Americans to the Moon emerged from a rapid but searching assessment of what space activity would best achieve a dramatic space "first" before the Soviet Union, thereby both enhancing U.S. prestige and serving as the focal point for the development of various space capabilities. It was this decision process that can best be characterized as rational. For example, veteran budget official Willis Shapley, who had been observing national security policy choices since he joined the BOB in 1942, commented that "after having been through quite a few major decisions, there was never a major decision like this made with the same degree of eyesopen, knowing-what-you're getting-in-for" character. Science adviser Jerome Wiesner agreed, saying that he and Kennedy "talked a lot about do we have to do this. He said to me, 'Well, it's your fault. If you had a scientific spectacular on this earth that would be more useful—say desalting the ocean-or something that is just as dramatic and convincing as space, then we would do it.' We talked about a lot of things where we could make a dramatic demonstration-like nation building - and the answer was that there were so many military overtones as well as other things to the space program that you couldn't make another choice." Wiesner added that "if Kennedy could have opted out of a big space program without hurting the country in his judgment, he would have." Also, "these rockets were a surrogate for military power. He had no real options. We couldn't quit the space race, and we couldn't condemn ourselves to be second." Time/Life reporter Hugh Sidey suggests that the Moon project "was a classic Kennedy challenge. If it hadn't been started, he might have invented it all, since it combined all those elements of intelligence, courage, and teamwork that so intrigued John Kennedy." Some years later, the admiring Sidey added that in deciding to go to the Moon, Kennedy "heard the poets. He was beyond politics and dollars" (Sidey, 1983: 69).

The final words on why he decided to go to the Moon belong to President Kennedy himself. We have in a tape recording of his November 21, 1962, meeting 
with his space and budgetary advisers an uncensored record of his thinking on the reasons behind his commitment. Then he said:

- "This is important for political reasons, international political reasons. This is, whether we like it or not, in a sense a race."

- "I would certainly not favor spending six or seven billion dollars to find out about space no matter how on the schedule we're doing ... Why are we spending seven million dollars on getting fresh water from salt water, when we're spending seven billion dollars to find out about space? Obviously you wouldn't put it on that priority except for the defense implications. And the second point is the fact that the Soviet Union has made this a test of the system. So that's why we're doing it. So I think we've got to take the view that this is the key program. Everything we do ought really to be tied to getting on the Moon ahead of the Russians."

- "I'm not that interested in space."

- "We're talking about these fantastic expenditures which wreck our budget and all these other domestic programs and the only justification for it in my opinion to do it in this time or fashion is because we hope to beat them and demonstrate that starting behind, as we did by a couple of years, by God, we passed them."

\section{Commitment Reviewed and Reiterated}

It is important to realize that Kennedy's decision to go to the Moon was not made once and for all time in April and May 1961. By mid-1961, Kennedy began questioning the costs associated with Apollo, and several times in 1962 and again, more intensely, in 1963 there were intensive reviews of Apollo's cost and schedule, asking each time whether the benefits of going ahead as planned justified the very high costs involved. In 1963, Kennedy saw an opportunity to cooperate with the Soviet Union in going to the Moon as a means of reducing U.S. costs while achieving other important strategic objectives; if the Soviet Union had responded positively, it certainly would have changed the character of Project Apollo.

There was thus not a single decision to aim at a lunar landing, but rather a series of decisions, each time with alternative paths being considered and each time with the resulting choice being to proceed with the program to land Americans on the Moon "before this decade is out," either as a unilateral undertaking or cooperatively. Only at the very end of the Kennedy administration was 
serious consideration given to slipping the end of the decade schedule, and even then the decision made was to reject such slippage and to stay with the planned schedule.

Kennedy's consistently reiterated commitment to Apollo can be best understood in terms of how he carried out his presidency overall. Theodore Sorensen, as he prepared Columbia University lectures which were later published as his book Decision-Making in the White House, asked national security adviser McGeorge Bundy for suggestions on what to say. Bundy replied that "the modes of Presidential decision are enormously varied," that "decisions are made through the ceaseless process by which, if an administration is lively, recommendations and proposals are ground forward," and that in a sense "the entire presidential existence is ... a process of decision." Viewing JFK's commitment to Apollo in these terms is particularly useful. Bundy suggested that "the president's larger policies: an open door to Moscow, an open door to all underdog Americans, an open door to intelligence and hope, honor to bravery, equal sense of past and future, gallantry to beauty, and pride in politics" were "colors of a permanent palette" and were reflected "in the small as well as the large decisions, drawn from in a hundred ways." 3 Policies in the space arena were indeed a reflection of Kennedy's broader objectives as president. As Sorensen suggests, reflecting the multiple facets of Kennedy's space strategy:

I think the President had three objectives in space. One was to ensure its demilitarization. The second was to prevent the field to be occupied to the Russians to the exclusion of the United States. And the third was to make certain that American scientific prestige and American scientific effort were at the top. Those three goals all would have been assured in a space effort which culminated in our beating the Russians to the moon. All three of them would have been endangered had the Russians continued to outpace us in their space effort and beat us to the moon. But I believe all three of those goals would also have been assured by a joint Soviet-American venture to the moon.

The difficulty was that in 1961, although the President favored the joint effort, we had comparatively few chips to offer. Obviously the Russians were well ahead of us at that time ... But by 1963, our effort had accelerated considerably. There was a very real chance we were even with the Soviets in this

3 Memorandum from McG. B. (McGeorge Bundy) to Mr. Sorensen, "Decisions in the White House," March 8, 1963, John F. Kennedy Presidential Library. 
effort. In addition, our relations with the Soviets, following the Cuban missile crisis and the test ban treaty, were much improved—so the President felt that, without harming any of those three goals, we now were in a position to ask the Soviets to join us and make it efficient and economical for both countries.

President Kennedy himself explained the subtlety of his space strategy as he wrote Congressman Albert Thomas in the aftermath of his September 20, 1963, proposal at the United Nations that the journey to the Moon become a cooperative undertaking: "This great national effort and this steadily stated readiness to cooperate with others are not in conflict. They are mutually supporting elements of a single policy." Kennedy added: "If cooperation is possible, we mean to cooperate, and we shall do so from a position made strong and solid by our national effort in space. If cooperation is not possible-and as realists we must plan for this contingency too-then the same strong national effort will serve all free men's interest in space, and protect us also against possible hazards to our national security."

One analyst of the Kennedy presidency correctly comments that "there would have been no race to the moon without the Cold War; the space program became as much a part of that conflict as Cuba, Berlin, and Laos" (Giglio, 2003: 134). Whatever President Kennedy, Vice President Johnson, and NASA Administrator Webb said about the purposes of Project Apollo in their public rhetoric, from April 20, 1961, when Kennedy asked Johnson to identify "a space program that promises dramatic results in which we could win," it was well understood within the government that the primary objective of Apollo was winning a Cold War-inspired competition to be first to the Moon. To those more focused on the totality of the U.S. space program than was John Kennedy, it was also clear from 1961 on that a program aimed at sending Americans to the Moon could serve as a focal point for the development of space capabilities of strategic value for the United States. By 1963, President Kennedy had seemingly also embraced that view. The November 1963 "Special Space Report" recommending proceeding with Apollo on its then-planned schedule clearly stated that "principal purposes" of the lunar landing program were (1) "demonstrating an important space achievement ahead of the USSR"; (2) "serving as a focus for technological developments necessary for other space objectives and having potential significance for national defense"; and (3) "acquiring useful scientific and other data to the extent feasible." These were the reasons John F. Kennedy decided in 1961 to go to the Moon, and they remained the objectives of Apollo at the time of his death. 
This stability in the actual reasons for the lunar race served as the political foundation for White House decisions to allocate the massive resources required for Apollo's success, even after Kennedy's assassination. It is perhaps his willingness to stay the course in the face of increasing criticisms of the path in space that he had chosen that most indicates the quality and strength of John F. Kennedy's original decision to go to the Moon.

\section{Other Explanations}

Historian Roger Launius has been somewhat critical of explaining Kennedy's space decisions as the result of "an exceptionally deliberate, reasonable, judicious, and logical process." He finds such an explanation as overly "neat and tidy." Launius suggests that the strength of the rational choice model "is its emphasis on Kennedy's Apollo decision as a politically pragmatic one that solved a number of significant problems," and that its weakness is "its unwavering belief that individuals - and especially groups of individuals-logically assess situations and respond with totally reasonable consensus actions." He adds that "since virtually nothing is done solely on a rational basis this is a difficult conclusion to accept." Launius also wonders whether Kennedy's attraction to the race to the Moon was a reflection of his "quintessential masculinity."

Of course other considerations than logic were involved in decisions related to the race to the Moon. The question is whether a rational approach was the predominant influence on policy choice in the 1961-1963 period, even as politics and personalities also played a part. A rational decision process can address both solving current problems as well as finding a way to achieve longer-term goals. Certainly the immediate stimulus to the decision to go to the Moon was the threat to U.S. global leadership posed by the world's reaction to Soviet space successes at the same time as the United States looked weak in its conduct of the Bay of Pigs fiasco. Kennedy's desire to regain his personal prestige and his administration's momentum were also problems addressed by the Apollo choice. Finding a way at the same time to move away from current problems and to pursue a worthy goal is an optimum policy-making objective, and Kennedy's space strategy was well-crafted to achieve this outcome. Of course, John Kennedy shared with others in his family an intensely competitive personality, and that characteristic certainly influenced the way he interpreted the U.S.-Soviet space

4 LAUNIUS, Roger D. Kennedy's Space Policy Reconsidered: A Post-Cold War Perspective. Air Power History, Winter 2003, 18-19 and Roger D. Launius, Interpreting the Moon Landings: Project Apollo and the Historians, History and Technology, v. 22, September 2006, p. 227. 
relationship. He constantly used references to "a race," the need for "winning" and being "first" in both his public and private comments on space. ${ }^{5}$ As Manned Spacecraft Center director Robert Gilruth commented, "he was a young man; he didn't have all the wisdom he would have had. If he'd been older, he probably would never have done it." It was a combination of Kennedy's youthful faith in the future, his fundamentally competitive personality, and his broader conception of the national interest that made him willing to accept the costs and risks of the lunar enterprise.

In 1964, political scientist Vernon van Dyke (1964: 137) suggested that Kennedy's need to restore national pride, which van Dyke characterized as "a need for national achievement and national morale" and as "gratification stemming from actual or confidently anticipated achievement," was the basic motivation for the decision to initiate the U.S. lunar landing program. John Kennedy came to the White House believing that by the force of his personality combined with forward-looking government actions he could "get this country moving again"; the combined shocks of the world reaction to the Gagarin flight and the Bay of Pigs fiasco challenged this belief. While restoring national (and perhaps personal) morale was indeed one of President Kennedy's goals, it seems to me that he saw pride in American society and its achievements not primarily in domestic terms but more as an element of U.S. "soft power" - the ability of the United States to "obtain the outcomes it wants in world politics because other countries want to follow it, admiring its values, emulating its example, aspiring to its level of prosperity and openness." ${ }^{6}$ In Kennedy's thinking about Project Apollo, both pride and power were elements of a policy initiative aimed primarily at influencing other nations of the world. As he said in his May 25, 1961, speech announcing the decision to go to the Moon, "no single space project in this period will be more impressive to mankind."

In summary then, I conclude that President Kennedy's commitment to a lunar landing program as the centerpiece of an effort to establish U.S. space leadership was the result of thoughtful consideration, particularly given that it was reiterated a number of times between May 1961 and November 1963. The commitment was publicly embellished with rhetorical flourishes, but at its core was a Cold War-driven but rational policy choice.

5 See Linda Krug, Presidential Perspectives on Space Exploration: Guiding Metaphors from Eisenhower to Bush. New York, Praeger, 1991, for a discussion of Kennedy's language as he justified Apollo.

6 On soft power, see Joseph S. Nye, Jr. The Paradox of American Power: Why the World's Only Superpower Can't Go It Alone, New York, Oxford University Press, 2002, pp. 4-9. 
The commitment also reflected values deeply embedded in the national psyche. When I wrote The Decision to Go to the Moon over forty years ago, my analysis of that decision reflected what Launius has correctly characterized as "a fundamentally liberal perspective on U.S. politics and society" and a celebration of "the use of federal power for public good." I suggested then that the Apollo decision reflected assumptions at the core of Western liberal philosophy. That man can do whatever he chooses, given only the will to do it and the techniques and resources required, is a belief that reflects motivations and characteristics basic to Western and particularly American civilization-a will to action, confidence in man's mastery over nature, and a sense of mission. Specific decisions on what a government should do are made by its leaders, and ideally reflect a lasting conception of the national interest rather than more parochial concerns or the specifics of their character. Through such decisions, the values and aspirations of a society can then be expressed through state action. John Kennedy embraced this activist perspective; in his much-respected June $1963 \mathrm{com}$ mencement address at American University, he suggested that "our problems are man-made - therefore, they can be solved by man. And man can be as big as he wants. No problem of human destiny is beyond human beings. Man's reason and spirit have often solved the seemingly unsolvable."

I would today revise my 1970 assessment, but only somewhat. The liberal perspective - that it is appropriate for the Federal government to undertake large-scale programs aimed at the public good-has been embraced by American presidents such as Woodrow Wilson, notably Franklin D. Roosevelt with his New Deal initiatives, John F. Kennedy and, after Kennedy, by Lyndon Johnson and Barack Obama, as well as by the more progressive elements of the U.S. political community. Other presidents and the more conservative elements among U.S. intellectuals, media, and most probably the majority of the general public are, in contrast, skeptical of both the appropriateness and the feasibility of largescale government programs aimed at societal improvement. So the proposal to focus massive government resources on a lunar landing effort in fact reflected only one of the two dominant strains in American political thought, the one that sees government steering of U.S. society as legitimate.

Conservative thinking as it applies to the commitment to Apollo was best articulated by historian Walter McDougall in his 1985 prize-winning study... the Heavens and the Earth. McDougall suggests that Kennedy's proposal that the

7 KENNEDY, John Fitzgerald. Commencement Address at American University. June 10, 1963 at <http:// www.presidency.ucsb.edu/ws/index.php?pid=9266\&st=\&st1=>. Access in: 03 jun. 2019. 
United States send Americans to the Moon "amounted to a plea that Americans, while retaining their free institutions, bow to a far more pervasive mobilization by government, in the name of progress." The lunar landing decision was part of JFK's assumption that some areas of "private behavior, when they involved the common security and well-being of the country" should be "susceptible to political control," expressed through a "growing technocratic mentality." He suggests that Project Apollo and the other initiatives proposed by Kennedy in his first months in office resulted in "an American-style mobilization that was one step away" from the Soviet approach to a planned society. To McDougall (1985: 305-306), "the commitment to go to the moon did more than accelerate existing trends in space. It served as the bridge over which technocratic methods passed from the military to the civilian realm."

Some justification for McDougall's concern about the impulses behind the lunar landing decision can be found in the language used in the May 8, 1961, report signed by James Webb and Robert McNamara that recommended setting a voyage to the Moon as a national goal. In portions of the report embodying themes first suggested by McNamara assistant John Rubel, the report argued that the diffusion of U.S. research and development efforts during the 1950s, especially in the national security sector, had had "a strong adverse effect on our capacity to do a good job in space." While the report did not suggest "that we apply Soviet type restrictions and controls upon the exercise of personal liberty and freedom of choice ... we must create mechanisms to lay out and insist on achievement." This call for concentration of effort was also found in Wernher von Braun's April 29, 1961, letter to Vice President Johnson. Von Braun concluded his letter by noting that "in the space race we are competing with a determined opponent whose peacetime economy is on a wartime footing... I do not believe we can win this race unless we take some measures which thus far have been considered acceptable only in times of a national emergency."

Overall, however, McDougall's analysis is derived more from his overall conservative perspective than from the facts of the situation in 1961-1963. While those charged with implementing the lunar mission individually went to extraordinary lengths to achieve success, neither John Kennedy's nor James Webb's management approach called for strong centralized control. The policy and budget decisions that steered Apollo in its early years were made through the normal decision-making process, not in a war-time or Soviet style. It was not the decision to go to the Moon that "militarized" civilian decision-making and led to such initiatives as President Johnson's Great Society and James Webb's attempts to use the space program as an instrument of change with respect to 
the U.S. educational and research systems. Those impulses stretched back to the activist presidency of Franklin D. Roosevelt. Both Johnson and Webb were committed New Dealers who used their positions in government to take actions that in their view would be for the common good.

The debate over the appropriate role of the federal government in undertaking large-scale efforts on behalf of the U.S. citizenry is a continuing one, and a full discussion of that role is well beyond the scope of this essay. What can be discussed, however, is what lessons can be drawn from the Apollo experience, and particularly from the way it was initiated by President John Kennedy, should there be a desire to begin another very expensive multiyear government initiative.

\section{If We Can Put a Man on the Moon...}

Project Apollo became the twentieth-century archetype of a successful, large-scale, government-led program. As peacetime engineering endeavors sponsored by the government, only the construction of the Panama Canal between 1904 and 1914 and the construction of the Interstate Highway System over several decades beginning in the 1950 s rivaled Apollo in terms of the scope and difficulty of the task and the scale of human and financial resources required. The success of Apollo has also led to the cliché, "if we can put a man on the Moon, why can't we . . ?? In their 2009 book titled with that cliché, Eggers and O'Leary (2009: xi) suggest that "democratic governments can achieve great things only if they meet two requirements: wisely choosing which policies to pursue and then executing those policies."

I believe that a study of Project Apollo demonstrates that it met both of these requirements for success. Eggers and O'Leary attribute much of the successful execution of the lunar landing program to the leadership of NASA administrator James Webb. I suggest that many others, both within and outside of NASA, should share credit for that implementation success, including particularly John Kennedy. ${ }^{9}$ President Kennedy gave Webb a great deal of freedom to manage NASA as Webb saw fit. A number of times between 1961 and 1963 Kennedy heard from others, often science adviser Jerome Wiesner or budget director David Bell, who questioned or disagreed with the path chosen by Webb. In

8 EGGERS, William D.; O'LEARY, John. If We Can Put a Man on the Moon:Getting Big Things Done in Government. Cambridge, MA, Harvard Business School Press, 2009, xi. 
particular, Wiesner waged a vigorous campaign to overturn NASA's choice of the lunar orbit rendezvous approach for carrying out the landing mission. NASA's head of manned spaceflight Brainerd Holmes let it be known to Kennedy that Webb opposed his suggestion that the schedule for the first lunar landing be accelerated; Kennedy shared Holmes's desire for the earliest possible landing. Even the Mercury astronauts took their plea for an additional flight in the Mercury program directly to President Kennedy. In every instance, Kennedy deferred to Webb as the individual responsible for carrying out the space program and thus the person who should make these decisions. Kennedy's style as chief executive was to seek as much information as possible in formulating his policy choices, but once a decision was made, Kennedy seldom intervened in its execution.

In my 1970 book, I suggested that "the experience of the lunar landing decision can be generalized to tell us to proceed toward other 'great new American enterprises." I set out in that book four conditions that seemed to me to be requirements for making a wise decision regarding an ambitious future objective:

1. The objective sought must be known to be feasible, with a high degree of probability, at the time the decision to seek it is made.

2. The objective must have been the subject of sufficient political debate so that the groups interested in it and opposed to it can be identified, their positions and relative strengths evaluated, and potential sources of support have time to develop.

3. Some dramatic "occasion for decision," such as a crisis resulting from an external or domestic challenge, must occur to create an environment in which the objective and the policies to achieve it become politically feasible.

4. There must be in leadership positions in the political system individuals whose personalities and political philosophies support the initiation of new large-scale government activities aimed at long-term payoffs and who have the political skill to choose the situations in which such activities can be initiated successfully.

Even writing in 1970, I recognized that the first of these conditions was very limiting, and would not work when the end desired required both technological breakthroughs and significant changes in deep-seated behavior patterns. However, I thought that "finding objectives with high social utility which could be achieved by a specific time using technologies, either physical or social, which are based on existing knowledge is not difficult." (Logsdon, 1970: 181). Almost 50 
years later, I find these comments either remarkably optimistic or remarkably naïve, probably both. What was unique about going to the Moon is that it required no major technological innovations and no changes in human behavior, just mastery over nature using the scientific and technological knowledge available in 1961. There are very few, if any, other potential objectives for government action that have these characteristics.

The reality is that attempts to implement other large-scale nondefense programs over the past forty years have never been successful, in the space sector or in the broader national arena. President George H. W. Bush in 1989, President George W. Bush in 2004, and President Barack Obama in 2010 set out ambitious visions for the future of space exploration, but none of those visions became reality; the political and budgetary support needed for success were notably missing. The fate of current proposals by President Donald Trump to return Americans to the Moon is unclear.

In the nonspace sector, there have been few opportunities for large-scale government programs that do not require for their success a combination of technological innovation and significant changes in human behavior. The attempts to declare a "War on Cancer," for example, required not only research breakthroughs but also changing the smoking habits of millions of Americans. Attempts to move toward U.S. "energy independence" run afoul both limited research and development spending and the complex ties between non-U.S. energy suppliers and the U.S. financial and government sectors. Providing adequate health care for all Americans turns out to be primarily a political, not merely a technical, challenge. Managing global environmental change has both high technical uncertainties and challenging social inertia to overcome. And so on.

Given this situation, I am now inclined to accept an alternative explanation that I rejected years ago: that the lunar landing decision and the efforts that turned it in into reality were almost unique occurrences, a once-in-a-generation, or much longer, phenomenon in which a heterogeneous mixture of factors almost coincidentally converged to create a national commitment and enough momentum to support that commitment through to its fulfillment. If this is indeed the case, then there is little to learn from the decision to go to the Moon relevant to twenty-first century choices. This would make the lament "if we can put a man on the moon, why can't we ...?" almost devoid of useful meaning except to suggest the possibility that governments can succeed in major undertakings, given the right set of circumstances. Other approaches to carrying out large-scale government programs will have to be developed; the Apollo 
experience has little to teach us beyond its status as a lasting symbol of a great American achievement.

\section{Apollo's Impacts}

Indeed, it may be the symbolic character of America's voyages to the Moon that is the most important heritage of the Apollo program. Certainly the images of the Earth rising over the barren lunar surface taken by Apollo 8 astronaut Bill Anders on Christmas Eve 1968 and of Apollo 11's Buzz Aldrin standing next to the American flag at "Tranquility Base" have become iconic, communicating to subsequent generations that the United States did years ago achieve something unique in human experience, the first steps off the home planet.

John Kennedy chose to go to the Moon as a means of restoring the U.S. prestige that he judged had been lost during the Eisenhower administration. In the shorter term, he also wanted to counteract the prestige loss caused by the conjunction of the Soviet success with the flight of Yuri Gagarin and the U.S. failure at the Bay of Pigs. Kennedy in 1961 conceptualized prestige in a way well described by British diplomatic historian F. S. Oliver thirty years earlier:

What prestige is, it would be hard to describe precisely, It may be nothing more substantial than an effect produced upon the international imagination -in other words, an illusion. It is, however, far from being a mere bubble of vanity; for the nation that possesses great prestige is thereby enabled to have its way, and to bring things to pass which it could never hope to achieve by its own forces. Prestige draws material benefits in its train. Political wisdom will never despise it. ${ }^{10}$

In terms of both shorter-term and more lasting impacts on U.S. international prestige and the associated national pride, Apollo was a substantial success. Within months of JFK's clarion call, NASA and U.S. industry were mobilized in a high-profile pursuit of the lunar landing goal. By declaring that the United States intended to take a leading position in space, and by then taking the steps to turn that declaration into practice, Kennedy effectively undercut the

10 F. S. Oliver, The Endless Adventure, Volume II, quoted in Giles Alston, International Prestige and the American Space Program, unpublished doctoral dissertation, St. Antony's College, Oxford University, 1989, pp. 8-9. A copy of Alston's thesis, which is an excellent analysis of the links between space achievement and national prestige, can be found in the NASA Headquarters Library in Washington, DC. 
unilateral Soviet space advantage in dramatic space achievements well before any comparable U.S. success. The successive achievements of Projects Mercury and Gemini, and most notably the February 1962 first U.S. orbital flight of John Glenn, became initial steps in JFK's lunar quest and thus made the U.S. space program of the 1960 s a source of international prestige and national pride. The psychological and political advantages of early Soviet space successes were quickly and effectively countered.

The success of Apollo 11 in July 1969 and five subsequent missions to the lunar surface (Apollo 13, of course, had a major failure on the way to the Moon and did not complete its landing mission) cemented the international perception of the United States as a country committed to peaceful space achievements "for all mankind." Americans who were abroad at the time of the first Moon landings, U.S. diplomats, and Apollo astronauts returning from post-mission international tours all attested to an immense flow of admiration for the country that could accomplish such a feat. Veteran high-level State Department officer U. Alexis Johnson reported that "There is no question that the success of Apollo 11 mission did more to bolster prestige abroad than any single event since the termination of the Pacific War in 1945." Johnson added a qualification, noting that "no one could hope or expect that the euphoric burst of enthusiasm felt by most of the world toward our country ... could be long maintained-nor has it been." According to Johnson, "we are left, however, with a very substantial residue of admiration and prestige. While benefits are impossible to measure in quantitative terms, these gains should be of very real value with respect to our posture in the world and our relations abroad for many years to come." ${ }^{11}$ John Kennedy could not have hoped for a better report on the success of his 1961 lunar landing decision.

We now know that during the Kennedy administration the United States was racing only itself to the Moon. While by 1963 the Soviet Union had begun to develop a large space rocket capable of sending a cosmonaut to the Moon, it had not yet decided to use it for lunar missions. It was not until spring 1964 that Central Intelligence Agency (CIA) analysts identified activity at the Soviet launch site in central Asia as a launch complex for a very large rocket. Until then, the CIA in its intelligence estimates had basically assumed without supporting hard evidence that the Soviet Union was pursuing a lunar landing program, both because that was a logical extension of past Soviet space activities and because the United States had identified a lunar landing as the appropriate goal

11 Johnson is quoted in Alston, International Prestige and the American Space Program, pp. 258-259. 
for human space flight and intelligence analysts reasoned that the Soviet would follow the same course. ${ }^{12}$

Kennedy was aware in 1961 that his decision to go to the Moon was being made without knowledge of Soviet space intentions; he decided that the prestige benefits of the lunar landing program required that the United States be first to the Moon, whether or not the Soviet Union was in the race. But he continually referred to U.S.-Soviet competition in going to the Moon in his public statements defending his decision. This was certainly the politically expedient thing to do; it would have been far more difficult to maintain political support for Apollo if the threat of Soviet competition had been absent. Several of President Kennedy's advisers in 1962 and 1963 alerted Kennedy to the lack of evidence in support of Soviet lunar intentions, and Kennedy was quite aware of the mid-1963 claims by Bernard Lovell that the Soviets did not have a lunar landing program. By then, he seems to have accepted James Webb's argument that the U.S. lunar program was an extremely valuable focal point for developing overall U.S. space capability, and that it should proceed, cooperatively if possible but unilaterally if not, even if the Soviet Union did not have a similar program.

Both during the Kennedy administration and during the rest of the 1960s (and even until today), critics have argued that the Apollo program was an unfortunate reflection of misplaced U.S. priorities. President Kennedy was aware of these criticisms, and in 1963 worked to prepare answers to the program's doubters. Apollo came to culmination at a time when the United States was experiencing urban riots, civil rights conflicts, political assassinations, and a seemingly pointless war in Southeast Asia. Kennedy cannot be faulted for not anticipating the domestic and international upheavals of the 1960s that changed the social context in which the lunar landings actually took place. In starting Apollo, Kennedy gave more weight to the situation in 1961 than to the longerterm situation in which the landings would actually take place. From his perspective in spring 1961, Apollo looked like the right thing to do.

All in all, then, an evaluation of Project Apollo in terms of the objectives that led John Kennedy to initiate and sustain it must be positive. Although it is impossible clearly to separate the positive impacts of Apollo from the many negatives of the decade of the 1960 s, if not for the achievements of the U.S. space program at the end of the decade there would be little positive for Americans to remember from that time.

12 See Asif Sidiqqi, Challenge to Apollo: The Soviet Union and the Space Race, 1945-1974, NASA SP-20004408 and John Logsdon and Alain Dupas, How Real was the Race to the Moon? Scientific American, June 1994 for a discussion of the Soviet lunar program. 


\section{Apollo's Impact on the U.S. Space Program}

By contrast, the impact of Apollo on the evolution of the U.S. space program has on balance been negative. Apollo turned out to be a dead end undertaking in terms of human travel beyond the immediate vicinity of this planet; no human has left Earth orbit since the last Apollo mission in December 1972. Writing in 1970, I suggested that the capabilities developed for Apollo would have "broad and significant impacts on human existence in the decades to come." Like many others close to the space program, I was caught up in the excitement of the initial lunar landing, and could not conceive of the possibility that having served its political purposes, Apollo and whatever human exploration efforts might follow it would so rapidly be brought to a close.

What happened, however, was that most of the Apollo hardware and associated capabilities, particularly the magnificent but very expensive Saturn V launcher, quickly became museum exhibits to remind us, soon after the fact, of what once was had been done. Commenting on this reality in 1989, Walter McDougall lamented the fate of Apollo: "a brilliant creation, carrying tremendous emotional baggage for the nation, achieved so quickly through such skilled and dedicated teamwork, only to be discarded, dismembered, or disinherited.' Columnist Charles Krauthammer at the time of the fortieth anniversary of the Apollo 11 mission in 2009 deplored the fact that humans have not returned to the Moon since the last Apollo mission: "On it are exactly 12 sets of human footprints-untouched, unchanged, abandoned. For the first time in history, the Moon is not just a mystery and a muse, but a nightly rebuke. A vigorous young president once summoned us to this new frontier, calling the voyage 'the most hazardous and dangerous and greatest adventure on which man has ever embarked.' And so we did it. We came. We saw. Then we retreated."

This rapid retreat should not have come as a surprise to careful observers. By being first to the Moon, the United States achieved the goal that had provided the sustainable momentum that powered Apollo; after Apollo 11, that momentum very rapidly dissipated, and there was no other compelling rationale to continue. In 1969 and 1970, even as the initial lunar landing missions were taking place, the White House canceled the final three planned trips to the Moon. President Richard Nixon had no stomach for what NASA proposed-a major post-Apollo program aimed at building a large space station in preparation for eventual (in the 1980s!) human missions to Mars. Instead, Nixon decreed, "we must think of them [space activities] as part of a continuing process ... and not as a series of separate leaps, each requiring a massive concentration of energy. 
Space expenditures must take their proper place within a rigorous system of national priorities ... What we do in space from here on in must become a normal and regular part of our national life and must therefore be planned in conjunction with all of the other undertakings which are important to us.' ${ }^{13}$ Nixon's policy view quickly reduced the post-Apollo space budget to less than \$3.5 billion per year, a Federal budget share one-quarter of what it had been at the peak of Apollo. There were in the 196os proposals, called the Apollo Applications Program, to use Apollo hardware for a variety of Earth orbit and deep space missions. Only one of those missions, the Skylab space station, ever came to fruition; its May 1973 launch was the last use of the Saturn V. The booster's production line had been shut down in 1970. The 1975 Apollo-Soyuz Test Program mission was the last use of an Apollo spacecraft and the Saturn $1 \mathrm{~B}$ launch vehicle. With the 1972 decision to begin the shuttle program, followed in 1984 with the related decision to develop a space station, the United States basically started over in human space flight, limiting itself since 1972 to orbital activities in the near vicinity of Earth.

The policy and technical decisions not to build on the hardware developed for Apollo for follow-on space activities were inextricably linked to the character of President John Kennedy's deadline for getting to the Moon - "before this decade is out." By setting a firm deadline for the first lunar landing, Kennedy put NASA in the position of finding a technical approach to Apollo that gave the best chance of meeting that deadline. This in turn led to the development of the Saturn V launcher, the choice of the lunar orbit rendezvous approach for getting to the Moon, and the design of the Apollo spacecraft optimized for landing on the Moon. Perceptive observer Richard Lewis in 1968 spoke of the "Kennedy effect," noting that

the political decision to send men to the moon also led to unexpected results in the development of space technology ... It has determined the priorities, the engineering designs, and the scientific objectives of the space program in this decade, and it is quite likely to control future space work for the remainder of this century. This unforeseen result might be called the Kennedy effect. While its intent at the beginning was to enlarge American competence in space, its implementation has built a Procrustean bed and the American space program has been severely mutilated to fit it (Lewis, 1968: 2).

13 NIXON, Richard M. Statement about the Future of the United States Space Program, March 7, 1970. Disponible in: <http://www.presidency.ucsb.edu/ws/index.php?pid=2903\&st=\&st1=>. Access in: 03 jun. 2019 . 
The consequences of selecting the lunar orbit approach to the Moon landing were of concern to Kennedy's science adviser Jerome Wiesner as he opposed the LOR choice in 1962. President Kennedy in his determination to be first to the Moon overruled Wiesner, a decision, as Lewis noted, with profound consequences for the space program. NASA during the second half of the 1960s became what James Webb had feared, a one-program agency; given the budget constraints of the period, there was no money available for major new starts on alternative programs.

The "Kennedy effect" went well beyond rockets and spacecraft. The Apollo program created in NASA an organization oriented in the public and political eye toward human space flight and toward developing large-scale systems to achieving challenging goals. It created from Texas to Florida the institutional and facility base for such undertakings. With the White House rejection of ambitious post-Apollo space goals, NASA entered an extended identity crisis from which it has yet to emerge. Repetitive operation of the space shuttle and the extended process of developing and utilizing an Earth-orbiting space station have not been satisfying substitutes for another Apollo-like undertaking. NASA has never totally adjusted to a lower priority in the overall scheme of national affairs; rather, as the Columbia Accident Investigation Board observed in its 2003 report, NASA became "an organization straining to do too much with too little. ${ }^{14} \mathrm{All}$ of this is an unfortunate heritage of John Kennedy's race to the Moon.

Yale University organizational sociologist Gary Brewer in 1989 observed that NASA during the Apollo program came close to being "a perfect place" - the best organization that human beings could create to accomplish a particular goal. But, suggests Brewer, "perfect places do not last for long." NASA "perfected itself in the reality of Apollo, but that success is past and the lessons from it are now obsolete." The NASA of 1989, according to Brewer, was "no longer a perfect place" and was "deeply troubled." He added:

The innocent clarity of purpose, the relatively easy and economically painless public consent, and the technical confidence [of Apollo] ... are gone and will probably never occur again. Trying to recreate those by-gone moments by sloganeering, frightening, or appealing to mankind's mystical needs for exploration and conquest seems somehow futile considering all that has happened since Jack Kennedy set the nation on course to the Moon.

14 Columbia Accident Investigation Board, "Report," v. 1, August 2003, p. 209. The report can be accessed at $<$ http://caib.nasa.gov/>. Access in: 03 jun. 2019. 
Brewer's comments of more than two decades ago might usefully be applied to the twenty-first century NASA and its supportive space community, which still struggle to maintain the approach to human space flight developed during the Mercury, Gemini, and Apollo programs. It is well beyond the scope of this essay to discuss the future of the U.S. space exploration program; the point to make here is that the conditions that made Apollo possible and the NASA of the 1960s a "perfect place" were unique and will not reoccur. I agree with Brewer's conclusion that NASA needs "new ways of thinking, new people, and new means to come to terms and cope with social, economic, and political environments as challenging and harsh as deep space itself." ${ }^{15}$

\section{Apollo and History}

The set of judgments that led President John F. Kennedy to decide to send Americans to the Moon combined lasting characteristics of the American people, a conviction of American exceptionalism and a mission derived from that conviction, the geopolitical situation of early 1961, and the individual values and style that Kennedy brought to the White House. Apollo was a product of a particular moment in time. Apollo is also a piece of lasting human history. Its most important significance may well be simply that it happened. Humans did travel to and explore another celestial body. Apollo will forever be a milestone in human experience, and particularly in the history of human exploration and perhaps eventual expansion. Because the first steps on the Moon were seen simultaneously in every part of the globe (with a few exceptions such as the Soviet Union), Apollo 11 was the first great exploratory voyage that was a shared human experience-what historian Daniel Boorstin called "public discovery." John Kennedy's name will forever be linked with those first steps. Like other ventures into unknown territory, Apollo may not have followed the best route nor have been motivated by the same concerns that will stimulate future space exploration. But without someone going first, there can be no followers. In this sense, the Apollo astronauts were true pioneers.

Leaving the Earth gave the Apollo astronauts the unique opportunity to look back at Earth and to share what they saw. The Apollo 8 "Earthrise" picture is surely one of the iconic images of the twentieth century. It allowed us, as poet Archibald McLeish noted at the time, "to see earth as it truly is, small and blue and beautiful in that eternal silence where it floats" and "to see ourselves as

15 BREWER, Garry D. Perfect Places: NASA as an Idealized Institution. In Radford Byerly, Jr. (ed.) Space Policy Reconsidered. Boulder, CO, Westview Press, 1989, pp. 157-173. 
riders on the earth together, brothers on that bright loveliness in the eternal cold-brothers who truly know that they are brothers." ${ }^{16}$ That perception alone cannot justify the costs of going to the Moon, but it stands as a major benefit from going there, one that has influenced human behavior in many ways.

I hope that sometime in the future-if not in the coming decades then in the coming centuries-humans will once again choose to venture beyond the immediate vicinity of Earth. I believe that the urge to explore- to see what is over the next hill—is a fundamental attribute of at least some human cultures. Michael Collins, the Apollo 11 astronaut who remained in orbit as Armstrong and Aldrin experienced being on the Moon, has commented that the lasting justification for human space flight is "leaving" - going away from Earth to some distant destination. As future voyages of exploration are planned, I also hope that the United States chooses to be in the vanguard of a cooperative exploration effort involving countries from around the globe. There are two things I judge as certain, whenever those voyages take place. One is that they will not be like Apollo, a grand but costly unilateral effort racing against a firm deadline to reach a distant and challenging goal. The other is that President Kennedy's name will be evoked as humans once again begin to travel away from Earth. As he said in September 1962, "We set sail on this new sea because there is new knowledge to be gained, and new rights to be won, and they must be won and used for the progress of all people." John F. Kennedy, like the astronauts who traveled to the Moon during Apollo, was a true space pioneer.

\section{References}

BREWER, Garry D. Perfect Places: NASA as an Idealized Institution. In: Radford Byerly, Jr. (ed.) Space Policy Reconsidered. Boulder, CO, Westview Press, 1989, pp. 157-173. COLUMBIA Accident Investigation Board. Report, v. 1, August 2003, (209). Disponible in: <http://caib.nasa.gov/.>. Access in: 20 may 2019.

DYKE, Vernon Van. Pride and Power: The Rationale of the Space Program. Urbana, IL, University of Illinois Press, 1964.

EGGERS, William D.; O'LEARY, John. If We Can Put a Man on the Moon: Getting Big Things Done in Government. Cambridge, MA, Harvard Business School Press, 2009, xi. GIGLIO, James N. John F. Kennedy and the Nation. In: James N. Giglio and Stephen Rabe, Debating the Kennedy Presidency. Lanham, MD, Rowman \& Littlefield Publishers, 2003.

KENNEDY, John Fitzgerald. Commencement Address at American University. June 10, 1963. Disponible in: <http://www.presidency.ucsb.edu/ws/index. php?pid=9266\&st=\&st $=>$. Access in: 20 may 2019.

16 McLeish's poem appeared in The New York Times, December 25, 1968, p. 1. 
KRUG, Linda. Presidential Perspectives on Space Exploration: Guiding Metaphors from Eisenhower to Bush. New York, Praeger, 1991.

LAUNIUS, Roger D. Kennedy's Space Policy Reconsidered: A Post-Cold War Perspective, Air Power History, Winter 2003, 18-19 and Roger D. Launius, Interpreting the Moon Landings: Project Apollo and the Historians. History and Technology. v. 22, September 2006.

LEWIS, Richard S. The Kennedy Effect, Bulletin of the Atomic Scientists, March 1968.

LOGSDON, John and DUPAS, Alain. How Real was the Race to the Moon? Scientific American, June 1994.

LOGSDON, John M. The Decision to Go to the Moon: Project Apollo and the National Interest. Cambridge, MA, The MIT Press, 1970, 181, 178.

. John F. Kennedy and the Race to the Moon. New York, Palgrave Macmillan, 2010.

MEMORANDUM from McG. B. (McGeorge Bundy) to Mr. Sorensen, Decisions in the White House, March 8, John F. Kennedy Presidential Library, 1963.

MCDOUGALL, Walter. The Heavens and the Earth; A Political History of the Space Age. New York, Basic Books, 1985, pp. 305-306.

MURRAY, Charles; COX, Catherine Bly. Apollo: Race to the Moon. New York, Toucjstone Press, 1990.

NIXON, Richard M. Statement about the Future of the United States Space Program. March 7, 1970. Disponible in: <http://www.presidency.ucsb.edu/ws/index. php?pid=2903\&st=\&st1=> . Access in: 20 may 2019.

NYE Jr., Joseph S. The Paradox of American Power: Why the World's Only Superpower Can't Go It Alone. New York, Oxford University Press, 2002, pp. 4-9.

OLIVER, F. S. The Endless Adventure, Volume II, quoted in Giles Alston, International Prestige and the American Space Program, unpublished doctoral dissertation, St. Antony's College, Oxford University, 1989, pp. 8-9.

SCHLESINGER JR, Arthur Schlesinger. A Thousand Days: John F. Kennedy in the White House. Boston, Houghton Mifflin, 1965.

SIDEY, Hugh. Time. November 14, 1983.

SIDIQQI, Asif. Challenge to Apollo: The Soviet Union and the Space Race. 1945-1974, NASA SP-2000-4408.

Recebido em 18/01/2019

Aprovado em 18/06/2019

\section{Como citar este artigo:}

LOGSDON, John M. John F. Kennedy and the Race to the Moon. Contemporânea Revista de Sociologia da UFSCar, v. 9, n. 1, jan.- jun. 2019, pp. 55-78. 